University of Nebraska - Lincoln

DigitalCommons@University of Nebraska - Lincoln

To Improve the Academy

Professional and Organizational Development Network in Higher Education

1996

\title{
Monitoring The Pulse of The Faculty: Needs Assessment in Faculty Development Programs
}

Jon E. Travis

Dan Hursh

Gentry Lankewicz

Li Tang

Follow this and additional works at: https://digitalcommons.unl.edu/podimproveacad

Part of the Higher Education Administration Commons

Travis, Jon E.; Hursh, Dan; Lankewicz, Gentry; and Tang, Li, "Monitoring The Pulse of The Faculty: Needs Assessment in Faculty Development Programs" (1996). To Improve the Academy. 369.

https://digitalcommons.unl.edu/podimproveacad/369

This Article is brought to you for free and open access by the Professional and Organizational Development Network in Higher Education at DigitalCommons@University of Nebraska - Lincoln. It has been accepted for inclusion in To Improve the Academy by an authorized administrator of DigitalCommons@University of Nebraska - Lincoln. 
Travis, J. E., Hursh, D., Lankewicz, G., and Tang, L. (1996). Monitoring The Pulse of The Faculty: Needs Assessment in Faculty Development Programs. In L. Richlin (Ed.), To Improve the Academy, Vol. 15 (pp .95-113). Stillwater, OK: New Forums Press and the Professional and Organizational Development Network in Higher Education. Key words: Needs Assessment, Faculty Development Programs.

\section{Monitoring The Pulse of The Faculty: Needs Assessment in Faculty Development Programs}

\section{Jon E. Travis}

East Texas State University

\section{Dan Hursh}

West Virginia University

\section{Gentry Lankewicz}

University of South Alabama

\section{Li Tang}

The Ohio State University

Although needs assessment is a common and necessary element of faculty development programs, the process never seems to be as easy or as effective as we might like it to be. Sadly, the literature is relatively weak in this all-important area of responsibility. Such a problem, no doubt, is due in part to the individual environment of each institution. Based on a presentation at the 1995 POD Conference, this article reviews a number of institutional approaches to gathering data from faculty, which may suggest some options for the reader. 
One could not step twice into the same river; for other waters are ever flowing on to you

- Heraclitus

Development of faculty necessitates some procedure for gathering feedback from individuals to target their specific developmental needs. Understandably, institutions with veteran programs and/or directors of faculty development may have an established routine of data gathering that appears to serve the program well. Yet, the variety of personalities and an ever-changing associated political climate may necessitate the consideration of new options or twists to familiar processes of eliciting feedback from the faculty and staff.

Furthermore, a novice faculty development director often has a desperate need for additional background information on the entire process of needs assessment. A relatively inadequate coverage of this all-important topic for faculty developers in the available literature makes the problem even more critical. While a few sources suggest a somewhat comprehensive coverage of the needs assessment topic (Nickens, Purga, \& Noriega, 1980; Office of Institutional Development, 1993; Soriano, 1995), the bulk of the literature treats the subject much more superficially (Blackburn, Boberg, O’Connell, \& Pellino, 1980; Eble \& McKeachie, 1985; Fitch \& Kopp, 1990; Hilsen \& Wadsworth, 1988; Mullins, 1994; Young, 1987).

Consequently, the four of us embarked on an endeavor to partially fill this gap with a presentation at the 1995 POD Conference that would cover the value and methods of determining faculty needs and attitudes. While previously addressed by presenters at earlier conferences, needs assessment is clearly of sufficient importance to warrant revisiting the topic, particularly in print for greater access. The intent is to provide an overview of needs assessment along with at least four institutional applications for critical review and potentially a possible synthesis of "best" options.

\section{Overview of Needs Assessment}

Assessment is, essentially, a process for gathering useful and necessary information. The purpose of a specific assessment deter- 
mines, in large part, how the process will be conducted. Intended to supply practitioners with information relative to potential gaps in services provided for a client population, needs assessment can be a helpful endeavor in a wide range of activities. The particular needs of citizens, patients, customers, passengers, employees, parishioners, audiences, students, and faculty are frequently determined through a range of measurement procedures intended to inform those who can potentially satisfy the identified needs.

Because each campus may have a different approach to doing faculty development, the procedure for conducting needs assessment for faculty development should likewise be variable. The rationale for performing needs assessment as a part of a faculty development program may be based upon insufficient familiarity with faculty or hidden faculty needs. Essentially, the faculty developer requires the necessary information to insure that faculty will participate in and

\section{Figure 1}

Input Resources in Needs Assessment

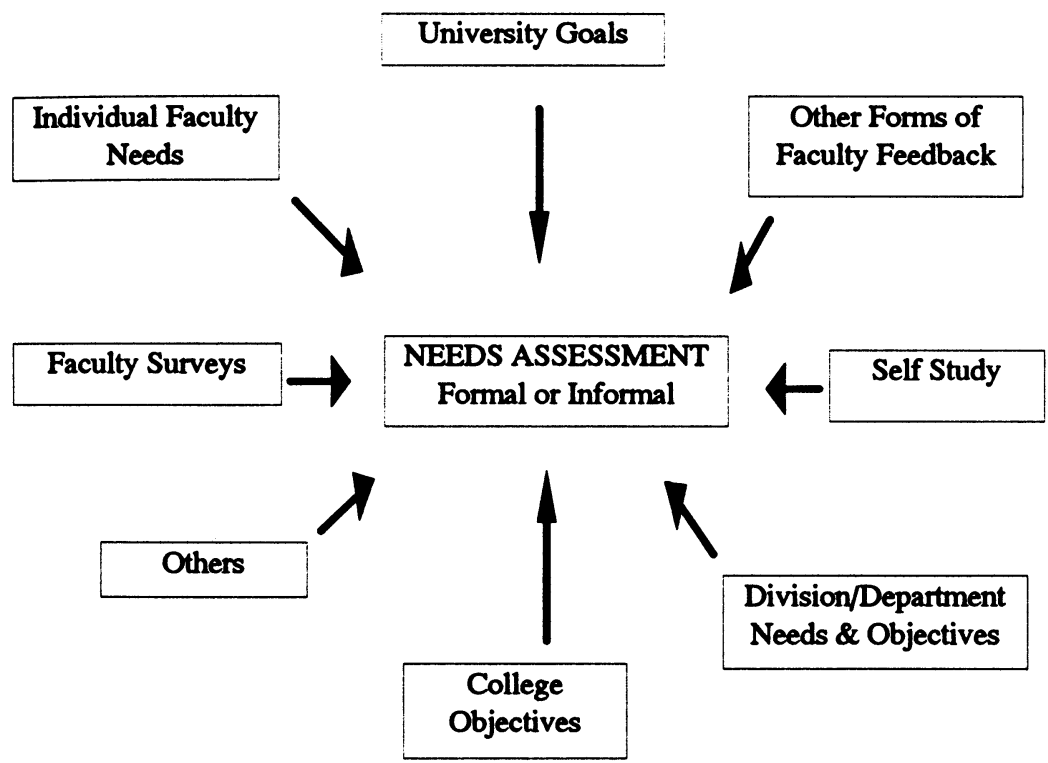


benefit from this highly personal and necessarily voluntary activity. As those well-versed in basic assessment methodology know, the use of multiple data collection methods is preferable for obtaining the most complete representation possible. Similar to other forms of assessment, faculty development needs assessment should maximize the procedures and the sources of applicable data. Some of these sources and procedures are suggested in Figure 1.

\section{Institutional Examples}

A synopsis of the needs assessment programs at four specific institutions follows. Additional options, suggested by session participants, are also included at the end of this section.

\section{East Texas State University}

Faculty development at East Texas State University (Commerce) is conducted by a committee of full-time faculty who oversee a series of social and academic events, publish a periodic newsletter, and provide support services in the form of resource materials and minimal travel funding. Due perhaps to this committee structure, needs assessment has not been a thorough or timely effort. Previously, faculty input has been sought primarily with broad surveys of the faculty at general faculty meetings at the start of the fall or spring semester.

The last such survey conducted before the fall semester, 1995, was distributed at the spring faculty meeting in 1993. Incorporating only topics for possible workshops, this survey was understandably limited in the data provided by the faculty for the Faculty Development Committee. A copy of the survey is in Appendix A. The results of the faculty survey clearly favored workshops dealing with critical thinking, student motivation, active learning techniques, and scholarly writing. A summary of results is shown in Table 1. Approximately two-thirds of the faculty attended the spring faculty meeting at which these forms were made available. The forms were placed on a table along with the meeting's agenda at the auditorium door. Yet, only 25 percent to 30 percent of the total faculty completed and returned the survey form. Considering the poor faculty attendance at the applicable 
workshops that resulted, this survey clearly was limited in its overall utility.

\begin{tabular}{|lcc|}
\hline \multicolumn{3}{|c|}{ TABLE 1 } \\
\multicolumn{3}{|c|}{ Spring 1993 Faculty Survey Results } \\
\hline & Number & $\begin{array}{c}\text { Average Score } \\
\text { (1-5 pref) }\end{array}$ \\
\hline Questionnaire ltem & 26 & 2.46 \\
\hline 1. Improving student motivation & 13 & 3.20 \\
2. Improving the quality of lectures & 13 & 2.84 \\
3. Alternatives to the lecture & 18 & 2.83 \\
4. Using collaborative learning & 30 & 2.73 \\
5. Teaching critical thinking & 24 & 3.08 \\
6. Active learning techniques & 13 & 3.30 \\
7. Constructing effective exams & 19 & 3.47 \\
8. Improving dassroom discussion & 17 & 2.64 \\
9. Dealing with large classes & 7 & 2.85 \\
10. Planning new courses & 13 & 3.38 \\
11. Handling the paper load & 6 & 2.83 \\
12. Writing across the curriculum & 7 & 3.85 \\
13. Training teaching assistants & 19 & 3.05 \\
14. Coping with faculty stress & 22 & 2.68 \\
15. Increasing scholarly writing & 10 & 3.30 \\
16. Dealing w/ diverse student populations & 17 & 3.58 \\
17. Making effective use of small groups & 18 & 2.83 \\
18. Developing teaching portfolios & 18 & 2.72 \\
19. Assessment alternatives to the exam & & \\
\hline
\end{tabular}

The next attempt to assess the faculty's needs utilized a survey once again. Surveys were provided on a table at the fall, 1995, faculty meeting. This form, however, requested faculty feedback on the entire faculty development program sponsored by the committee A copy of the survey is in Appendix B. Nevertheless, with between two-thirds and three-fourths of the faculty in attendance at the meeting, only 25 percent of the faculty responded to the survey. Since all of the faculty development activities were included on this form, the utility of the feedback from the faculty was understandably greater. A summary of results is shown in Table 2.

Yet another survey form was included in the first issue of the Faculty Development Newsletter distributed in October, 1995. A copy 
of the survey is in Appendix C. Although the results of the previous survey indicated that the newsletter was the most frequently used resource provided by the committee, less than twenty responses to the newsletter were returned. The low percentage of survey responses in each case emphasize the primary drawbacks of the survey form for newsletter were returned. The low percentage of survey responses in each case emphasize the primary drawbacks of the survey form for needs assessment: responses come primarily from participants and response rates are generally low.Anticipating such a problem with surveys, the committee chair initiated a project to interview all of the faculty on campus (approximately 250). In addition to insuring 100 percent feedback for a complete needs assessment picture, the purpose of the project was also to address the committee's lack of familiarity

\begin{tabular}{|c|c|c|c|c|}
\hline \multicolumn{5}{|c|}{$\begin{array}{c}\text { TABLE } 2 \\
\text { Fall } 1995 \text { Faculty Survey Results }\end{array}$} \\
\hline Events Attended & Never & Once or twice & Often & Alwlays \\
\hline $\begin{array}{l}\text { Workshops } \\
\text { Socials: }\end{array}$ & 11 & 25 & 9 & 2 \\
\hline Morning coffee & 28 & 9 & 7 & 2 \\
\hline Afternoon social & 15 & 14 & 16 & 3 \\
\hline Luncheon Meetings & 23 & 14 & 9 & 1 \\
\hline Faculty book discussion & 23 & 16 & 4 & 4 \\
\hline Publications & $\begin{array}{l}\text { Never } \\
\text { Read }\end{array}$ & $\begin{array}{l}\text { Read One or } \\
\text { Two }\end{array}$ & Often Read & $\begin{array}{c}\text { Read Every } \\
\text { one }\end{array}$ \\
\hline Teaching Professor & 3 & 13 & 17 & 15 \\
\hline Innovation Abstracts & 12 & 13 & 14 & 9 \\
\hline F. D. Newsletter & 1 & 7 & 20 & 19 \\
\hline Activity & $\begin{array}{c}\text { No } \\
\text { opinion }\end{array}$ & Continue & $\begin{array}{l}\text { Replace w/ } \\
\text { other event }\end{array}$ & \\
\hline Workshops & 7 & 38 & 4 & \\
\hline Socials & 12 & 30 & 7 & \\
\hline Faculty Retreat & 18 & 20 & 12 & \\
\hline Travel minigrants & 9 & 36 & 3 & \\
\hline Faculty Abroad Program & 16 & 27 & 6 & \\
\hline $\begin{array}{l}\text { Guest speaker for Fall/Spring } \\
\text { meetings }\end{array}$ & 14 & 21 & 14 & \\
\hline Primary assignment: & $\begin{array}{l}\text { Faculty } \\
40\end{array}$ & $\begin{array}{l}\text { Dept. Head } \\
4\end{array}$ & $\begin{array}{l}\text { Dean/Admin. } \\
5\end{array}$ & \\
\hline
\end{tabular}


with the entire faculty. The open-ended, qualitative interviews, which are not yet complete, include the following questions: What is the most important component of your role as a faculty member? What do you need to accomplish this aspect of your role? What can faculty development do to help you accomplish this task?

These interviews are likely to provide the kind of insight into faculty attitudes and motivation that written response forms cannot accomplish. While the task is expected to be arduous and time-consuming, particularly because the committee chair is conducting all of the interviews, the results of the project should provide a significant return for such an investment.

Unlike other faculty development programs, the committee has not typically surveyed the faculty participants during the course of each individual activity. Because of the low attendance rates for the actual activity functions, the results of such surveys would probably be of less use than simply recording the number of participants. These participant data have been especially helpful in altering the content and number of such functions.

Another weakness perceived in the needs assessment agenda is the lack of feedback provided to the faculty following each assessment. In the past, little or no response to faculty input has been included, thus understandably jeopardizing future assessment efforts. Now that this shortcoming in the faculty development program has been recognized, steps are underway to rectify the problem.

\section{The Ohio State University}

The faculty development program at The Ohio State University began in 1980 as Instructional Development and Evaluation. In 1986, the unit changed its name to Faculty and TA Development (FTAD) and became part of the Center for Teaching Excellence (CTE). The CTE became the Center for Instructional Resources within Academic Computing Services (ACS) in 1992. The university's academic reconstruction moved FTAD from ACS to the College of Education in 1994.

With approximately 3400 full-time faculty, 1100 part-time faculty, and 2500 graduate teaching associates, the university's potential clientele for FTAD services is quite large. To collect the necessary 
needs assessment data for its program, the office conducts both a long-term, continuing process of regular, small-scale assessments and periodic, large-scale, campus-wide studies. Since its inception, the office has systematically solicited faculty and TA development needs via various sources to draw conclusions, to make decisions, and to implement programs.

Of the two needs assessment strands conducted by FTAD, the continuous approach requires the greatest investment of time and energy. The most important of these on-going assessment endeavors is program evaluation of events. Participants of most FTAD activities are asked to evaluate these events to provide information on how they feel about the programs and what future events they would prefer. See an example of the survey in Appendix D. The evaluation forms are completed and collected at the conclusion of each event. Results are sorted, analyzed, and synthesized to determine the significance of each program and possible future programs. In addition to the evaluation forms, the office collects quantitative data on hosted events that reflect the number and demographics of participants, the optimum timing of each activity, and the suggested frequency of events for future decision making.

Another source of data for continuous assessment is the individual consultation, through which faculty can discuss their concerns with FTAD instructional development specialists. Follow-up evaluation of consultations, incorporating questionnaires completed by consultation clients, often provide additional insight into their particular needs. Input on needs is also acquired through idea exchanges with peer institutions, requests by individual academic units, and cooperative efforts with other academic service units on campus.

The much less frequent, campus-wide studies included a first-year series of focus groups, followed by two surveys, conducted in 1989 and 1992 respectively, of the entire faculty through the University Faculty Poll. These studies sought to assess the faculty's general awareness of the (then) Center for Teaching Excellence and the services it provided. The survey further solicited feedback from those who had used any of these services. In addition, FTAD staff also conducted individual interviews, in 1992, with one-third of the 120+ academic department chairs to discuss their needs. In 1994, a small- 
scale interview and survey research study conducted by an FTAD staff member also gathered needs, impact, and satisfaction data.

Based on the experience with both types of needs assessment and given the size of the university and its wide range of program areas, advantages and disadvantages are apparent with each approach. The continuous, small-scale assessments appear to be more advantageous and effective. The feedback proves to be instant and fresh, with high quality and quantity, and the assessments are cost effective. In comparison, the periodic, large-scale, campus-wide assessments survey a larger population that includes the non-users of FTAD services, but tend to be time consuming, labor intensive, and costly.

\section{Southeastern Louisiana State University}

Among the fastest growing universities in the nation, Southeastern Louisiana State University (Hammond) maintains a faculty development program that is also a function of a faculty committee. Established in 1992, the 22-member committee was charged to provide program advocacy, fund disbursement recommendations, program advisory input, active participation in program events, and program tracking and evaluations.

A faculty development survey, entitled "Professional Development: Your Preference," was conducted during the spring semester, 1992. Designed with the assistance of the director of outcomes assessment, this survey was the initial endeavor to poll faculty for their faculty development needs. The questionnaire asked faculty what was needed to help them improve the teaching, research, and publication components of their roles.

A total of 155 of the 350 faculty members responded to the survey in the spring of 1992. The results of the survey suggested goals and activities that were assessed and incorporated into the committee's strategic plan for campus-wide faculty development. Activities were planned and initiated to include workshops, panel discussions, brown bag socials, and an annual professional enhancement workshop featuring national speakers and showcasing the faculty's accomplishments in development. The effectiveness of each activity was measured with a questionnaire, much as the Ohio State program has 
done. Results of these event surveys were reviewed by the committee, published, and shared with the faculty.

A content synthesis of faculty perceived needs and interests was used to prioritize program areas of emphasis and to utilize available institutional resources to support the idea of a program model for the campus. Citing the growing interest and involvement in faculty development, the committee fostered the design of a five-year plan to implement a model faculty development program. A crucial component for implementing this five-year plan involved a periodic review and update of needs assessment data. The committee agreed that such re-evaluation of needs would be a continuing and evolving project that would guide the program. In 1993, the committee created an evaluation plan for each component of the five-year plan as well.

One response to the faculty needs identified through the various needs assessment efforts has been the addition of a Faculty Productivity Lab in the campus library. Realizing the importance of technology in teaching, the administration granted funds for hardware and software in the center, with space provided by the library. Since the initiation of the faculty development program, the library faculty have actively participated in faculty development and have perceived themselves playing a key role in meeting faculty needs.

The commitment of both the faculty and the administration has significantly contributed to the establishment of an effective faculty development program. Like other campuses relying on this somewhat cumbersome committee structure, the Southeastern Louisiana program has a goal to metamorphose into a faculty development center with a full-time program. In the meantime, the mission to cater to the professional, instructional, and organizational development needs of the faculty continues.

\section{West Virginia University}

The Instructional Improvement Network (IIN) at West Virginia University was established in the summer of 1994 , to provide collegial support for instructional improvement. Its goal is to connect resources to needs across the university. The initial task of the IIN was to identify 
the resources and needs of faculty. This assessment was accomplished through a series of activities.

The first such activity was a faculty development session involving the description of some of the existing efforts by a few of the faculty. Those in attendance (approximately 35 ) then generated ideas about the characteristics of an instructional improvement network that could serve the needs of all the faculty on campus. This was followed by another faculty development session featuring a presentation describing a peer classroom observation system that is successfully operating at another institution. This provided an example of how one aspect of an instructional improvement network might work. A work session that followed involved approximately six faculty members who considered input from the first session and created a proposal for the network. The provost then provided funding for the proposal.

A peer observation system and an e-mail discussion group were established, and a survey was sent to the faculty. The survey announced the new programs and requested faculty to describe their needs, the resources they were willing to share, and other activities they might suggest for the IIN. There is an example of the survey in Appendix E. Of the 10 percent of the faculty responding, all requested to participate in the e-mail discussions, but only one-third agreed to offer their classes for observation. Needs and resources were listed by about one-fifth of those responding. A second survey during the following semester produced similar results, with the third semester responses declining further.

During the process of these surveys, the IIN provided topical discussion sessions, a session on the progress and prospects for the IIN, and an action planning session for those who coordinate instructional improvement activities for the various colleges and schools within the university. Each of these activities provided formal and informal opportunities for assessing the needs of faculty and identifying existing resources. With minimal human and financial resources to operate the IIN, the assessment of needs and the identification of resources had to be simple, direct, and incomplete. Understandably, the assessment efforts will continue in this pragmatic fashion so long as the limited resources remain available. 


\section{Other Institutional Approaches}

At the National Technical Institute for the Deaf (NTID) at the Rochester Institute for Technology, the use of faculty surveys has been more successful with engineering faculty than with those in the arts and sciences. Faculty generally suggested that they simply be informed of the planned activities and they would decide whether to attend. Furthermore, the survey results often tended to be a determination of what individuals felt they needed for their own personal professional development, as opposed to institutional development. Some faculty developers at other institutions expressed concern that faculty may tend to identify what is important (to them) in their jobs, rather than what they need. To avoid being confined to such personal concerns, some developers suggested focusing more on the perspective of the institutional mission and student learning than on that of the faculty. Another institution has achieved some measure of success, at least in the construction of faculty survey instruments, by involving the university's college of business, which has designed statistically accurate surveys. A general consensus of the participants in the needs assessment session at the 1995 POD Conference confirmed that surveys generally do not work. The primary drawback seems to be inadequate responses.

Additional recommendations for gathering data on faculty and institutional needs included the use of advisory committees, like those often used for vocational programs, and applications for faculty development mini-grants, where available. Such data can suggest activities that interest faculty or areas that require specific attention.

\section{Critical Analysis and Conclusions}

Based on the components of the programs cited and the input from other faculty developers, some common caveats become apparent. First, and most importantly, to best monitor the pulse of the faculty, needs assessment should be conducted on a continuous, timely basis with variable approaches being used for data collection. Similarly, as we have learned from the Classroom Assessment Model (Angelo \& Cross, 1993), a response to the feedback provided is necessary to "close the loop" (p. 31). If the feedback is not thus recognized, the 
next request for feedback is likely to be met with skepticism and fewer responses.

While the survey instrument seems to be the weakest link in providing needs assessment data, it remains the simplest and most cost effective means of collecting the information. Likewise, the information-rich interview technique is much more costly, both in time and in resources. One suggestion to modify the time demands for the interview technique is to consider employing a team of interviewers. However, not only will this approach increase the resource investment, but the results may also be more difficult to manage with the possibility of variable perspectives.

Needless to say, the task of conducting needs assessment for faculty development is neither uncomplicated nor expeditious. Furthermore, the mood and the needs of the faculty are always changing. Like the river in Heraclitus' profound thought, each assessment is likely to paint a different picture. Hence, the task of assessing faculty needs for development is as incomplete as the development itself.

\section{References}

Angelo, T. A., \& Cross, K. P. (1993). Classroom assessment techniques: A handbook for college teachers. San Francisco: Jossey-Bass.

Blackburn, R.T., Boberg, A., O'Connell, C., \& Pellino, G. (1980). Project for faculty development program evaluation. Ann Arbor, MI: Center for the Study of Higher Education, University of Michigan.

Eble, K.E., \& McKeachie, W.J. (1985). Improving undergraduate education through faculty development: An analysis of effective programs and practices. San Francisco: Jossey-Bass.

Fitch, M.E., \& Kopp, O.W. (Eds.). (1990). Staff development for the practitioner: Planning, procedures, practices, and assessment. Springfield, IL: C.C. Thomas.

Hilsen, L., \& Wadsworth, E.C. (1988). Staging successful workshops. In E.C. Wadsworth (Ed.), A handbook for new practitioners (pp. 45-52). Stillwater, OK: New Forums.

Mullins, T.W. (1994). Staff development programs: A guide to evaluation. Thousand Oaks, CA: Sage.

Nickens, J.M., Purga, A.J., \& Noriega, P.P. (1980). Research methods for needs assessment. Washington, DC: University Press of America.

Office of Institutional Development. (1993). Staff development needs assessment. Valencia, CA: College of the Canyons. (ERIC Document Reproduction Service No. ED 376 989) 
Soriano, F. I. (1995). Conducting needs assessment: A multidisciplinary approach. Thousand Oaks, CA: Sage.

Young, R.E. (1987). Evaluating faculty development programs: Program goals first. In J.R. Wergin and L.A. Braskamp (Eds.), Evaluating administrative services and programs (New Directions for Institutional Research No. 56) (pp. 71-82). San Francisco: Jossey-Bass.

\section{Contact:}

Jon Travis

Department of Secondary \& Higher Education

Texas A\&M University - East Texas Station

Commerce, TX 75429 USA

(903) 886-5607

(903) 886-5603 FAX

Jon Travis is an Assistant Professor of Secondary and Higher Education and the Director of the Center for Community College Education at Texas A\&M University - Commerce.

Daniel Hursh is a Professor of Educational Psychology and one of the coordinators of the Instructional Improvement Network at West Virginia University.

Gentry Lankewicz is the Electronic Services Librarian at the University of South Alabama.

Li Tang is an Instructional Development Specialist at The Ohio State University.

The description of the West Virginia University faculty development program was prepared with the assistance of two other coordinators of the Instructional Improvement Network, Afzel Noore and Esther Gottlieb. 


\section{Appendix A}

\section{East Texas State University}

Spring 1993 Survey Form

Faculty Development Survey

In order to plan effective workshops for the coming year, the Faculty Development Committee is asking that faculty members take a moment to examine the following list of topics which might be considered for future discussion groups. Please select those items in which you might be interested, and number your first four of five choices in order of preference. If none of these topics is of interest, please take a moment to note any topics you might be interested in discussing at a faculty workshop.

\section{Improving student motivation}

2. Improving the quality of lectures

3. Alternatives to the lecture

4. Using collaborative learning

5. Teaching critical thinking

6. Active learning techniques

7. Constructing effective exams

8. Improving classroom discussion

9. Useful techniques for dealing with large classes

10. Planning new courses

11. Handling the paper load

12. Writing across the curriculum

13. Training teaching assistants

14. Coping with faculty stress

15. Increasing production of scholarly writing

16. Dealing with diverse student populations

17. Making effective use of small groups

18. Developing teaching portfolios

19. Assessment alternatives to the exam

Other ideas: 


\section{Appendix B}

East Texas State University

Fall 1995 Survey Form

Faculty Development Survey

Please indicate your prior participation in the following activities:

$0-$ Never attended

2-Attended often

1-Attended once or twice

3-Always attended

Workshops (e.g., SIS, Publication, Taxes)

Socials:

Morning coffee

Afternoon social

Luncheon Meetings

Faculty book discussion

Use of publications:
0 -Never read
1 - Read one or two
2-Often read
3-Read every one

\section{Teaching Professor}

Innovation Abstracts

Faculty Development Newsletter

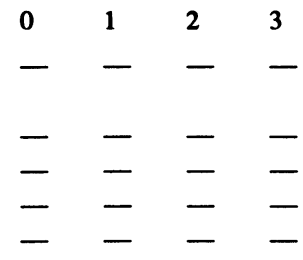

Please indicate below your recommendations for Faculty Development activities

0-No opinion

1-Continue

2-Replace with suggestion below

Workshops

Socials

Faculty Retreat

Travel mini-grants

Faculty Abroad Program

Guest speaker for Fall/Spring faculty meetings

Suggestions for workshops/replacement activities:

$\begin{array}{cccc}0 & 1 & 2 & 3 \\ - & - & - & - \\ - & - & - & -\end{array}$

Primary assignment (please check one): Faculty_ Dept. Head__ Dean/Admin. 


\section{Appendix C \\ East Texas State University \\ Newsletter Survey Form}

Opinions about the new look for the Faculty Development Newsletter:

I wish to review the following book for LIONOTES:

I have an article/idea to contribute to the newsletter as follows:

Please include me on the list of faculty willing to collaborate.

Please send me a copy of the Kappan article when it arrives.

Name (please print)

Dept.

(Please return via campus mail to Jon Travis) 


\section{Appendix D \\ The Ohio State University \\ New Faculty Network (Winter 1995)}

In Winter Quarter 1995, the Office of Faculty and TA Development coordinated four New Faculty Network (NFN) meetings. You attended some or all sessions. For our information and better planning in the future, we would greatly appreciate it if you can take a few minutes to complete the following questionnaire. Your input is very important to us.

1. What do you think of the topics we selected for the NFN meetings?

2.What did you like most about the sessions and handouts we have shared with you?

3. What did you like the least about the sessions and/or handouts?

4. What other faculty development programs would you like our office to facilitate in the future?

Thank you for your support and prompt response. Please return the questionnaire before March 24 to Marsha Jones, Faculty and TA Development, 20 Lord Hall, 124 W. 17th Ave., CAMPUS. Thanks. 


\section{Appendix E \\ West Virginia University \\ Fall 1995 Instructional Improvement Resources Survey}

Name Dept/Program

Address Phone Email

I am interested in participating in the Peer Visitation Program by opening my class to fellow faculty members.

Course Number and Title

Room Number and Building

Students Served:

\section{Class Time}

Student Enrollment Beginning Undergraduates Advanced Undergraduates Graduates

Please check all teaching methods that apply:

_problem-solving

_cooperative group learning

_field trips audiovisual

_computer-aided instruction

_role playing

_discussion groups

_others (describe)

_lecture
_independent study
_multimedia distance learning
_individualized instruction
_case studies
_projects

_lecture

independent study

_multimedia distance learning

case studies

projects

Please describe some of the teaching activities in your class. This information will help interested faculty in selecting classes to visit.

I am interested in subscribing to the Instructional Improvement Network (IIN) email discussion group.

yes

no

I am interested in receiving help in the following areas pertaining to instructional improvement.

I am interested in providing help to other faculty in the following areas pertaining to instructional improvement.

I am interested in attending a seminar on Instructional Improvement regarding:

Topic(s)

Possible speakers from WVU or outside

What other initiatives should the Instructional Improvement Network pursue to promote excellence in teaching and learning at WVU?

PLEASE RETURN ASAP. RESPONSES RECEIVED BY SEPTEMBER 11, 1995 WILL ENSURE INCLUSION ON THE PEER VISITATION LIST, WHICH WILL BE DISTRIBUTED TO ALL FACULTY 